\title{
Pengaruh Model Pembelajaran Talking Stick Berbantuan Media Question Card Terhadap Kompetensi Pengetahuan IPA
}

\author{
Ni Nyoman Tri Angraeni Widhyalestari1*, DB. Kt. Ngr. Semara Putra², I Wayan \\ Darsana $^{3}$
}

123 Jurusan Pendidikan Dasar, Universitas Pendidikan Ganesha, Singaraja, Indonesia

\begin{abstract}
Abstrak
Penelitian ini bertujuan untuk mengetahui pengaruh yang signifikan model pembelajaran Talking Stick berbantuan media Question Card terhadap kompetensi pengetahuan IPA siswa kelas IV SD Gugus I Mengwi Tahun Ajaran 2018/2019. Jenis penelitian ini adalah penelitiaan eksperimen semu (quasy experimental design) dengan rancangan penelitian nonequivalen control group design. Populasi dari penelitian ini adalah seluruh kelas IV SD Gugus I Mengwi yang berjumlah 6 kelas (187 siswa). Sampel diambil dengan teknik random sampling. Sampel dalam penelitian ini adalah siswa kelas IV SD No. 4 Cemagi dengan 30 siswa sebagai kelompok eksperimen dan siswa kelas IV SD No. 3 Cemagi dengan 32 siswa sebagai kelompok kontrol. Data tentang kompetensi pengetahuan IPA dikumpulkan dengan instrumen berupa tes objektif pilihan ganda biasa berjumlah 30 butir soal. Selanjutnya data dianalisis dengan menggunakan uji-t. berdasarkan hasil analisis data diperoleh ratarata gain skor kelompok eksperimen $\mathrm{X}=0.500>\mathrm{X}=0.262$ kelompok kontrol, selanjutnya melalui uji hipotesis diperoleh $\mathrm{t}_{\text {hitung }}=9.231>\mathrm{t}_{\text {tabel }}=2.000$ pada taraf signifikan $5 \%$ dengan $\mathrm{dk}=60$ sehingga $\mathrm{H}_{0}$ ditolak $\mathrm{H}_{\mathrm{a}}$ diterima. Hal ini berarti terdapat perbedaan yang signifikan model pembelajaran Talking Stick berbantuan media Question Card terhadap kompetensi pengetahuan IPA siswa kelas IV SD Gugus I Mengwi Tahun Ajaran 2018/2019. Dengan demikian dapat disimpulkan bahwa model pembelajaran Talking Stick berbantuan media Question Card berpengaruh terhadap kompetensi pengetahuan IPA siswa kelas IV SD Gugus I Mengwi Tahun Ajaran 2018/2019.
\end{abstract}

\begin{abstract}
This study aims to determine the significant effect of the Talking Stick learning model assisted by media Question Card on science knowledge competencies of fourth grade students in elementary school I Mengwi academic year 2018/2019. This type of research is quasy experimental design with a nonequivalent control group design. The population of this study were all class IV SD I Mengwi which consisted of 6 classes (187 students). The sampel is taken by random sampling technique. The sample in this study was fourth grade students of SD No. 4 Cemagi with 30 students as an experimental group and fourth grade students at SD No. 3 Cemagi with 32 students as a control group. Data on science knowledge competencies were collected with instruments in the from of ordinary multiple choice objective tests totaling 30 items. Then the data were analyzed using the $t$-test. Based on the results of data analysis, the average gain of the experimental group score $X=0,500>X=0.262$ control group, then through the hypothesis test obtained tcount $=9.231$ trabel 2.000 at a significant level $5 \%$ with $\mathrm{dk}$ $=60$ so ho is rejected $\mathrm{H}$ accepted. This means that there is a significant difference in the Talking Stick learning model assisted with Question Card media in science knowledge competencies of grade IV SD I Mengwi academic year 2018/2019. It can be concluded that the Talking Stick learning model assisted by the Question Card media has an effect on science knowledge competencies of grade IV SD I Mengwi academic year 2018/2019.
\end{abstract}

\footnotetext{
* Corresponding author.

E-mail Addresses: - triangraeniwidhyalestari@gmail.com (Ni Nyoman Tri Angraeni Widhyalestari)
} 


\section{PENDAHULUAN}

Pendidikan merupakan bagian yang sangat penting dalam proses pembangunan suatu bangsa dan negara, karena tanpa didukungnya pendidikan tidak mungkin pembangunan suatu bangsa dan negara dapat berkembang dengan baik. Kita dapat melihat contohnya yaitu perkembangan antara desa dengan kota, dimana kota bisa dianggap lebih berkembang dari pada desa dikarenakan sistem pembangunan yang dipimpin oleh orang-orang terpelajar. Pendidikan itu sebenarnya harus didapatkan oleh setiap lapisan masyarakat agar pembangunan suatu bangsa dan negara itu dapat berjalan dengan baik. Hal tersebut juga terlihat dalam UUD 1945 pasal 31 yang menyatakan bahwa setiap warga negara berhak mendapatkan pendidikan (Amandemen UUD 1945, Bab XIII tentang Pendidikan dan Kebudayaan). Pernyataan dalam pasal 31 itu sekaligus merupakan landasan dan jaminan bagi setiap warga negara Indonesia untuk memperoleh pendidikan tanpa membedakan suku, agama, dan golongan (Sirait, 2016).

Sekolah Pendidikan adalah hal yang utama bahkan wajib dilaksanakan oleh umat manusia. Dikarenakan pendidikan dapat membangun jati diri dan karakter siswa. Pendidikan juga berpengaruh besar terhadap pola pikir siswa, dimana pendidikan dapat menambah pengetahuan dan mengubah manusia menjadi orang yang berpengetahuan dan berwawasan luas. (Kompri, 2016:16) menyatakan bahwa "Pendidikan bagi umat manusia merupakan sistem dan cara meningkatkan kualitas hidup dalam segala bidang". Berarti melalui pendidikan siswa dapat menambah kemampuan dan keahlian sesuai bidang keahliannya. Dalam sejarah hidup umat manusia di muka bumi ini hampir tidak ada kelompok manusia yang tidak menggunakan pendidikan sebagai cara pembudayaan dan mengembangkan kualitas hidup. Pendidikan merupakan suatu hal yang sangat dibutuhkan oleh masyarakat sehingga pemerintah sebagai penyelenggara pendidikan formal selalu memajukan pendidikan bagi masyarakat karena dengan pendidikan akan melahirkan generasi penerus yang bertanggung jawab dan kreatif. Untuk memajukan pendidikan formal agar menjadi lebih baik, guru sebagai salah satu unsur yang berperan penting dalam program pemerintah pendidikan. Sehingga tujuan pendidikan yang berkualitas dapat dicapai oleh guru sesuai dengan kemampuan guru dalam mengorganisir siswanya.

Dengan demikian, guru haruslah memiliki kiat-kiat yang kuat dan motivasi yang tinggi agar tujuan pendidikan tersebut dapat berlangsung dengan baik. Dalam Undang-Undang Republik Indonesia No 20 Tahun 2003 pasal 3 tentang Sistem Pendidikan Nasional dikatakan bahwa. "pendidikan nasional bertujuan untuk berkembangnya potensi peserta didik agar menjadi manusia yang beriman dan bertakwa kepada Tuhan Yang Maha Esa, berakhlak mulia, sehat, cakap, berilmu, kreatif, mandiri dan menjadi warga Negara yang demokratis serta bertanggung jawab". Kompri (2016:16) menyatakan bahwa, tujuan pendidikan nasional yang mempunyai tujuan yang penting bagi kelangsungan kehidupan bangsa yang sedang membangun. Demikian pentingnya pendidikan bagi manusia sehingga mengharuskan manusia untuk dapat memperoleh pendidikan, baik pendidikan formal maupun pendidikan nonformal.

Disimpulkan bahwa tujuan dari pendidikan adalah setiap orang harus menempuh jalur pendidikan baik pendidikan formal maupun pendidikan nonformal utamanya bagi negara yang berkembang. Melalui pendidikan peserta didik dapat mengembangkan kemampuan diri dan intelektualnya agar dapat membuat negara berkembang bisa maju melalui pengetahuan di kemudian hari.

Usaha pemerintah untuk mengembangkan kualitas pendidikan siswa SD, salah satunya melakukan penyempurnaan kurikulum 1994 menjadi kurikulum 2004 yang lebih dikenal dengan Kurikulum Berbasis Kompetensi (KBK), namun disempurnakan lagi menjadi kurikulum tahun 2006 yang dikenal dengan Kurikulum Tingkat Satuan Pendidikan (KTSP), dan pada tahun 2013 pemerintah melakukan penyempurnaan kembali dengan Kurikulum 2013 (K13) yang dikenal saat ini. Salah satu tujuan dari penyempurnaan kurikulum tersebut adalah untuk meningkatkan mutu tenaga dan lembaga pendidikan, sehingga menjadi berkualitas dan profesional.

Berdasarkan teori-teori tersebut, dapat disimpulkan bahwa pendidikan merupakan proses dalam hidup seseorang untuk mencapai perubahan dan mewujudkan potensi dari diri seseorang menjadi lebih baik. Keberhasilan suatu pendidikan tidak pernah terlepas dari proses kegiatan pembelajaran yang dilaksanakan disekolah. Hal tersebut dapat dilihat pada kompetensi siswa.

Paradigma pendidikan terjadi diberbagai bidang disiplin ilmu. Dalam kurikulum 2013 salah satu muatan materi yang termuat yaitu Ilmu Pengetahuan Alam (IPA). Muatan IPA di SD menekankan pada pemberian pengalaman langsung dan siswa dituntut melakukan beberapa proses secara aktif mencari, mengolah, mengkonstruksi, dan menerapkan pengetahuan.

Wisudawati dan Sulistyowati (2015:45) menyatakan, IPA merupakan ilmu yang mempelajari tentang fenomena alam. Fenomena-fenomena alam yang dipelajari dalam IPA berasal dari fakta-fakta yang ada di alam dan hasil abstraksi pemikiran manusia. Ketika fenomena tersebut dijumpai oleh peserta didik maka proses konstruksi pengetahuan akan lebih mudah dibandingkan dengan IPA yang berasal dari abstraksi pemikiran manusia. 
"IPA adalah usaha manusia dalam memahami alam semesta melalui pengamatan yang tepat pada sasaran, serta menggunakan prosedur dan dijelaskan dengan penalaran sehingga mendapatkan suatu kesimpulan" Susanto (2014:167).

IPA adalah kumpulan teori yang sistematis tentang usaha manusia dalam memahami gejala-gejala alam semesta melalui pengamatan dan hasil percobaan yang tepat sasaran serta menggunakan prosedur, dan dijelaskan dengan penalaran sehingga mendapatkan suatu kesimpulan.

Dalam proses pembelajaran pada anak usia SD penerapan model-model pembelajaran membuat siswa aktif dan kreatif dalam mengikuti kegiatan pembelajaran. Berdasarkan hasil observasi yang dilakukan dengan guru kelas IV SD Gugus I Mengwi pada hari senin, 14 Januari 2019, proses pembelajaran belum menerapkan model-model pembelajaran yang inovatif. Berkaitan dengan ini, maka sangat dibutuhkan untuk menerapkan inovasi dalam model-model pembelajaran di SD Gugus I Mengwi yang dilakukan secara intensif oleh guru pada pembelajaran IPA. Selain penerapan model pembelajaran, media pembelajaran cukup berperan dalam mengoptimalkan kompetensi siswa. "Media adalah perantara atau pengantar pesan dari pengirim atau penerima pesan" (Arsyad, 2016:3). Oleh karena itu alangkah baiknya dalam pembelajaran diusahakan menggunakan pembelajaran yang menarik, menyenangkan dan berpusat pada siswa. Salah satu model pembelajaran tersebut adalah model pembelajaran Talking Stick. merupakan salah satu model pembelajaran yang inovatif membuat siswa lebih aktif dan semangat dalam proses belajar mengajar. Melalui model pembelajaran Talking Stick membangun kepribadian peserta didik untuk berani mengemukakan pendapat dan menuangkan potensi diri yang peserta didik miliki. Huda (2017:224) menyatakan "Talking Stick merupakan model pembelajaran kelompok dengan bantuan tongkat". Strategi ini diawali dengan penjelasan guru mengenai materi pokok yang akan dipelajari. Kemudian dengan bantuan stick (tongkat) yang bergulir sebagai giliran untuk menjawab soal peserta didik dituntun untuk merefleksikan atau mengulang kembali materi yang sudah dipelajari dengan cara menjawab pertanyaan dari guru. Untuk lebih menarik perhatian siswa dalam model pembelajaran ini maka dapat dibantu dengan memanfaatkan media Question Card. Model pembelajaran Talking Stick berbantuan media Question Card dapat mendukung sebuah pembelajaran yang efektif di kelas agar tercipta suasana belajar yang lebih menarik. Question Card dalam pembelajaran yaitu menarikan siswa pertanyaan-pertanyaan melalui kartu yang diberikan oleh guru pada saat pembelajaran berlangsung. (Novita, 2017). Model pembelajaran Talking Stick berbantuan media Question Card dalam proses belajar siswa dapat membuat suasana belajar yang berbeda dari pembelajaran sebelumnya dalam kelas.

Dari hal tersebutlah yang mendorong penelitian ini melaksanakan penelitian yang berjudul "Pengaruh Model Pembelajaran Talking Stick Berbantuan Media Question Card Terhadap Kompetensi Pengetahuan IPA Siswa Kelas IV SD Gugus I Mengwi Tahun Ajaran 2018/2019”.

\section{METODE PENELITIAN}

Penelitian ini dilaksanakan di kelas IV SD Gugus I Mengwi. Jenis penelitian yang digunakan adalah penelitian kuantitatif yaitu penelitian eksperimen dengan bentuk desain eksperimen semu (quasy experimental design). Sugiyono (2015:114) memaparkan bahwa, "Desain eksperimen semu (quasy experimental design) mempunyai kelompok kontrol tetapi tidak dapat berfungsi sepenuhnya untuk mengontrol variable-variabel luar yang mempengaruhi pelaksanaan eksperimen". "Subjek penelitian atau partisipan penelitian tidak dipilih secara acak untuk dilibatkan dalam kelompok eksperimen dan kelompok kontrol". (Setyosari, 2015:210). "Subjek penelitian atau partisipan penelitian tidak dipilih secara acak untuk dilibatkan dalam kelompok eksperimen dan kelompok kontrol”. (Setyosari, 2015:210). Dengan demikian, dalam penetapan random tidak memungkinkan memilih dan memilah subjek sesuai dengan rancangannya, akan tetapi menggunakan kelas atau kelompok subjek yang ditentukan oleh sekolah. Hal itu dikarenakan tidak mungkin mengacak-acak kelas yang sudah terstruktur oleh sekolah serta untuk mencegah kemungkinan subjek mengetahui dirinya dilibatkan dalam penelitian. Bentuk desain eksperimen semu yang digunakan dalam penelitian ini adalah non-equivalent control group design. Rancangan penelitian dapat dilihat dalam tabel di bawah ini.

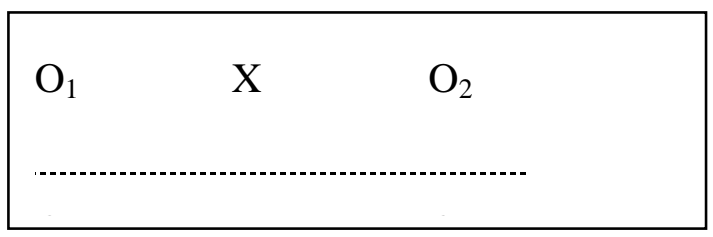

Gambar 1. Rancangan Eksperimen Non-Equivalent Control Group Design 
Keterangan :

$\mathrm{O}_{1}=$ Pre-test pada kelompok eksperimen

$\mathrm{O}_{2}=$ Post-test pada kelompok eksperimen

$\mathrm{O}_{3}=$ Pre-test pada kelompok kontrol

$\mathrm{O}_{4}=$ Post-test pada kelompok kontrol

$\mathrm{X}=$ Perlakuan pada kelompok eksperimen yang dibelajarkan dengan model Talking Stick berbantuan media Question Card.

Pada penelitian ini kelompok eksperimen dan kelompok kontrol sama-sama diberikan pre-test dan post-test. Pre-test dan post-test diberikan pada kelompok eksperimen dan kontrol. Kelompok eksperimen diberikan pembelajaran dengan menerapkan model pembelajaran Talking Stick berbantuan media Question Card sedangkan untuk kelompok kontrol memberikan pembelajaran konvensional. Kemudian setelah diberikan perlakuan, dilakukan post-test untuk mengetahui kompetensi pengetahuan IPA siswa.

Prosedur penelitian yang dilaksanakan dalam penelitian ini terdiri dari tiga tahapan yaitu, tahap persiapan eksperimen, tahap pelaksanaan eksperimen, dan tahap akhir eksperimen. Adapun uraiannya pada tahap persiapan eksperimen langkah-langkah yang dilakukan yaitu, melakukan wawancara dengan kepala gugus dan wali kelas IV di masing-masing sekolah untuk mengetahui ada atau tidaknya kelas unggulan di SD Gugus I Mengwi, menyusun RPP, LKS, beserta media pembelajaran yang digunakan dalam proses pembelajaran, mengkonsultasikan instrumen pre-test dan post-test bersama wali kelas dan dosen pembimbing, mengkonsultasikan RPP yang digunakan bersama wali kelas dan dosen pembimbing, mengadakan uji instrumen penelitian, menentukan sampel penelitian dengan menggunakan teknik random sampling, dan terakhir melakukan pengundian untuk menentukan kelompok eksperimen dan kelompok kontrol.

Pada tahap pelaksanaan eksperimen, langkah-langkah yang dilakukan yaitu, memberikan perlakuan pada kelompok eksperimen berupa model pembelajaran talking stick berbantuan media question card dan kelompok kontrol berupa pembelajaran konvensional, perlakuan diberikan sebanyak enam kali di kelas eksperimen dan enam kali juga di kelas kontrol, memberikan post-test pada akhir eksperimen, baik kelompok eksperimen maupun kelompok kontrol.

Pada tahap akhir eksperimen, langkah-langkah yang dilakukan yaitu, menganalisis data hasil penelitian, melakukan uji hipotesis, melakukan pembahasan, membuat kesimpulan, dan menyusun laporan.

Tujuan penelitian ini adalah untuk mengetahui perbedaan yang signifikan kompetensi pengetahuan IPA antara kelompok siswa yang dibelajarkan menggunakan model pembelajaran talking stick berbantuan media question card dan kelompok siswa yang dibelajarkan menggunakan model pembelajaran Konvensional pada siswa kelas IV SD Gugus I Mengwi Tahun Ajaran 2018/2019.

Dalam penelitian ini, subjek dalam penelitian diisitilahkan sebagai populasi dan sampel. Menurut Sugiyono (2015:117) "Populasi adalah wilayah generalisasi yang terdiri atas: objek/subjek yang mempunyai kualitas dan karakteristik tertentu yang ditetapkan oleh penelitian untuk dipelajari dan kemudian ditarik kesimpulannya". Sedangkan menurut Setyosari (2015:221) menyatakan bahwa "Populasi merupakan keseluruhan dari objek, orang, peristiwa, atau sejenisnya yang menjadi perhatian dan kajian dalam penelitian".

Berdasarkan beberapa pendapat tersebut dapat disimpulkan bahwa pengertian populasi adalah kumpulan dari objek/subjek atau sejenisnya yang menjadi perhatian dan dikaji dalam penelitian mengenai hasil perhitungan maupun pengukuran kemudian ditarik kesimpulan.

Populasi dari penelitian ini adalah seluruh siswa kelas IV SD Gugus I Mengwi Tahun Ajaran 2018/2019 yang terdiri dari 6 SD. Jumlah populasi dari penelitian ini adalah 187 siswa.

Setelah mengetahui populasi langkah selanjutnya adalah menentukan sampel penelitian. "Sampel ialah sebagian dari populasi yang diambil, yang dianggap mewakili seluruh populasi dan diambil dengan menggunakan teknik tertentu" (Agung, 2014:69). Menurut Sugiyono (2015:81) "Sampel adalah bagian dari jumlah dan karakteristik yang dimiliki oleh populasi tersebut". Sejalan dengan hal tersebut Setyosari (2015:221) menyatakan "sampel itu merupakan sejumlah kelompok kecil yang mewakili kelompok populasi untuk dijadikan sebagai objek penelitian". Dari beberapa pendapat para ahli dapat dirangkum bahwa sampel adalah bagian dari populasi yang mewakili anggota populasi. Dari pengertian tersebut memberi gambaran bahwa sampel mewakili populasi untuk dijadikan sebagai sumber data penelitian. Penggunaan sampel bertujuan untuk menghemat waktu, tenaga, dan biaya dalam melakukan penelitian. "Pengambilan sampel harus memenuhi syarat representatif artinya sampel yang diambil benar-benar mewakili populasi yang ada (representative)" (Setyosari, 2015:222). 
Teknik pengambilan sampel pada penelitian ini adalah Random Sampling sehingga setiap kelas mendapatkan peluang yang sama untuk menjadi sampel penelitian. Random Sampling merupakan cara pengambilan sampel dengan memberikan kesempatan yang sama kepada anggota populasi untuk diambil menjadi anggota sampel (Agung, 2014). Dari hasil observasi dan wawancara dengan kepala gugus bahwa semua kelas IV SD yang ada di Gugus Mengwi setara dalam hal input dan output dari perolehan hasil belajar, yang berarti tidak ada kelas unggulan maupun non unggulan. Sehingga semua kelas IV SD yang ada di Gugus Mengwi mendapat peluang yang sama untuk menjadi anggota sampel. Pemilihan sampel penelitian ini tidak dilakukan pengacakan individu melainkan hanya pengacakan kelas. Kelas dipilih sebagaimana telah terbentuk tanpa campur tangan peneliti dan tidak dilakukannya pengacakan individu, kemungkinan pengaruh-pengaruh dari keadaan siswa mengetahui dirinya dilibatkan dalam eksperimen dapat dikurangi sehingga penelitian ini menggambarkan pengaruh perlakuan yang diberikan. "Teknik sampel random dapat dilakukan dengan beberapa cara, yaitu undian, ordinal, bilangan random" (Agung, 2014:72).

Untuk menentukan sampel, cara yang digunakan adalah dengan cara pengundian. Cara undian dilakukan dengan menulis semua kelas IV di SD Gugus Mengwi pada masing-masing kertas yang jumlahnya 6 kelas, kemudian kertas digulung. Masukkan gulungan kertas ke dalam kotak dan lakukan pengundian untuk mendapatkan dua kelas. Setelah itu, dua kelas hasil pengundian diberikan pre-test, kemudian nilai atau skor dari hasil pre-test yang dilakukan tersebut digunakan untuk penyetaraan kelas sampel. Untuk penyetaraan kelas sampel, nilai atau skor dari hasil pre-test dianalisis menggunakan uji-t. Sebelum uji kesetaraan menggunakan uji-t, maka data hasil pre-test diuji prasyarat yaitu uji normalitas sebaran data dan uji homogenitas varians. Jika data pre-test yang diperoleh sudah memenuhi prasyarat uji normalitas dan homogenitas barulah dianalisis menggunakan uji-t. Setelah terdapat kelas yang diketahui setara secara akademik, maka dilakukan pengundian untuk menentukan kelas eksperimen dan kelas kontrol. Kesetaraan sampel diuji dengan rumus uji-t yakni dengan polled varian sebagai berikut.

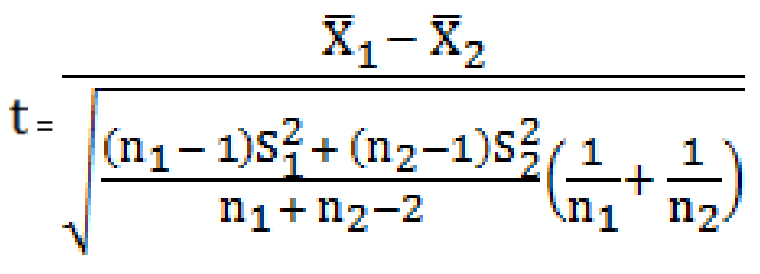

(Sugiyono, 2015:197)

Keterangan:

$\mathrm{S}_{1}{ }^{2}=$ varians kelompok eksperimen

$\mathrm{S}_{2}{ }^{2} \quad=$ varians kelompok kontrol

$\overline{\mathrm{X}}_{1} \quad=$ rerata nilai pre-test kelas eksperimen

$\overline{\mathrm{X}}_{2} \quad=$ rerata nilai pre- test kelas kontrol

$\mathrm{n}_{1} \quad=$ jumlah siswa kelas eksperimen

$\mathrm{n}_{2} \quad=$ jumlah siswa kelas kontrol

Adapun rekapitulasi hasil uji normalitas sebaran data hasil pre-test, kompetensi pengetahuan IPA siswa kelas IV SD Gugus I Mengwi Tahun Ajaran 2018/2019 disajikan pada tabel berikut.

Tabel 1. Rekapitulasi Hasil Uji Normalitas Sebaran Data Hasil Pre-test Kompetensi Pengetahuan IPA

\begin{tabular}{ccccc}
\hline No & Sampel & {$\left[\mathrm{F}_{\mathrm{t}}-\mathrm{F}_{\mathrm{s}}\right]$} & $\begin{array}{c}\text { Nilai Tabel Kolmogorov- } \\
\text { Smirnov }\end{array}$ & Keterangan \\
\hline 1. & Kelas IV SD No. 4 Cemagi & 0.118 & 0.242 & Berdistribusi Normal \\
2. & Kelas IV SD No. 3 Cemagi & 0,134 & 0,234 & Berdistribusi Normal \\
\hline
\end{tabular}

Berdasarkan Tabel 1, data pre-test kelas IV SD No. 4 Cemagi diperoleh $\left[\mathrm{F}_{\mathrm{t}}-\mathrm{F}_{\mathrm{s}}\right]=0.118$ dan nilai tabel Kolmogorov-Smirnov $=0.242$, karena $\left[\mathrm{F}_{\mathrm{t}}-\mathrm{F}_{\mathrm{s}}\right]=0.118<$ nilai tabel KolmogorovSmirnov $=0.242$, maka data berdistribusi normal (perhitungan lebih lengkap pada lampiran). Perhitungan uji normalitas sebaran data pre-test di kelas IV SD No. 3 Cemagi diperoleh $\left[F_{t}-F_{s}\right]=$ 
0,134 dan nilai tabel Kolmogorov-Smirnov $=0,234$, karena $\left[\mathrm{F}_{\mathrm{t}}-\mathrm{F}_{\mathrm{s}}\right]=0,134<$ nilai tabel Kolmogorov-Smirnov $=0,234$, maka data berdistribusi normal.

Setelah uji normalitas dilakukan, selanjutnya dilakukan uji homogenitas. Uji homogenitas varians dilakukan dengan menggunakan uji $F$. kriteria pengujian jika $F_{\text {hitung }}<F_{\text {tabel, }}$, maka sampel homogen. Pengujian dilakukan pada taraf signifikan 5\%.

Tabel 2. Rekapitulasi Hasil Uji Homogenitas Varians Hasil Pre-test Kompetensi Pengetahuan IPA

\begin{tabular}{cccccccc}
\hline No & Sampel & $S_{1}{ }^{2}$ & $S_{2}{ }^{2}$ & $\mathrm{Dk}$ & $\mathrm{F}_{\text {hitung }}$ & $\mathrm{F}_{\text {tabel }}$ & Keterangan \\
\hline 1. & $\begin{array}{c}\text { Uji Homogenitas } \\
\text { Varians }\end{array}$ & 6.576 & 5.339 & 30,32 & 1.23 & 1.83 & Homogen \\
\hline
\end{tabular}

Berdasarkan uji homogenitas varians $\mathrm{F}_{\text {hitung }}=1.23$ dan $\mathrm{F}_{\text {tabel }}=1.83$, karena $\mathrm{F}_{\text {hitung }}=1.23<$ $\mathrm{F}_{\text {tabel }}=1.83$ maka data homogen. (perhitungan lebih lengkap pada lampiran). Data pre-test dari kedua kelompok sampel berdistribusi normal dan homogen dilanjutkan dengan melakukan diuji kesetaraan dengan uji-t. berikut hasil analisis uji kesetaraan pre-test kompetensi pengetahuan IPA.

Tabel 3. Hasil Analisis Uji Kesetaraan Sampel

\begin{tabular}{ccccccccc}
\hline No & Sampel & $\mathrm{N}$ & $\mathrm{Dk}$ & $\mathrm{X}$ & $\mathrm{S}^{2}$ & $\mathrm{t}_{\text {hitung }}$ & $\mathrm{t}_{\text {tabel }}$ & Keterangan \\
\hline 1. & Kelas IV SD No. 4 & 30 & 60 & 19.900 & 6.576 & 1,258 & 2.000 & Setara \\
$\begin{array}{l}\text { Cemagi } \\
\text { Kelas IV SD No. 3 }\end{array}$ & 32 & & 19.125 & 5.339 & & & \\
& Cemagi & & & & & & & \\
\hline
\end{tabular}

Berdasarkan hasil analisis didapat $t_{\text {hitung }}=1,258$ dan $t_{\text {tabel }}$ pada taraf signifikansi $5 \%$ dengan derajat kebebasan $\mathrm{dk}=\left(n_{1}+n_{2}-2\right)=60$. Sehingga $t_{\text {hitung }}=1,258<\mathrm{t}_{\text {tabel }}=2.000$, artinya Ho diterima kelompok dinyatakan setara. Kemudian peneliti melakukan pengundian pada kedua sampel untuk menentukan kelompok eksperimen dan kelompok kontrol. Setelah diundi untuk menentukan kelompok eksperimen dan kelompok kontrol, undian yang muncul adalah SD No. 4 Cemagi dengan jumlah siswa 30 sebagai kelompok eksperimen dan SD No. 3 Cemagi dengan jumlah siswa 32 sebagai kelompok kontrol.

Penelitian ini memiliki 2 variabel, yaitu variabel terikat dan variabel bebas. Variabel terikat adalah variabel yang dipengaruhi atau yang menjadi akibat, karena adanya variabel bebas (Sugiyono, 2015). Menurut (Setyosari, 2015) menyebutkan variabel terikat adalah faktorfaktor yang diobservasi dan diukur untuk menentukan adanya variabel bebas. Dengan demikian variabel terikat adalah variabel yang menjadi penyebab karena adanya variabel bebas. Variabel terikat dalam penelitian ini adalah kompetensi pengetahuan IPA siswa.

Variabel bebas adalah variabel yang menyebabkan atau memengaruhi, yaitu faktor-faktor yang diukur, dimanipulasi, atau dipilih oleh peneliti untuk menentukan hubungan antara fenomena yang diobservasi atau diamati (Setyosari 2015). Selanjutanya Menurut Sugiyono (2017:39) "variabel bebas adalah merupakan variabel yang mempengaruhi atau yang menjadi sebab perubahan atau timbulnya variabel dependen (terikat)". Dengan demikian variabel bebas adalah variabel yang menjadi penyebab munculnya variabel terikat. Variabel bebas dalam penelitian ini adalah Model Pembelajaran talking stick berbantuan media question card.

Data yang dikumpulkan dalam penelitian ini diperoleh dari hasil pre-test dan post-test yang dianalisis menggunakan gain skor normalisasi untuk memperoleh data kompetensi pengetahuan IPA. Setelah pre-test diberikan, siswa kemudian belajar menggunakan model pembelajaran talking stick berbantuan media question card pada kelompok eksperimen dan belajar dengan pembelajaran konvensional pada kelompok kontrol.

Untuk mendapatkan data tersebut digunakan tes kompetensi pengetahuan IPA. Menurut Arikunto (2015:67) "tes merupakan alat atau prosedur yang digunakan untuk mengetahui atau 
mengukur sesuatu dalam suasana, dengan cara atau aturan-aturan yang sudah ditentukan". Tes yang digunakan untuk mengumpulkan data dalam penelitian ini adalah tes objektif dalam bentuk pilihan ganda biasa meliputi empat pilihan jawaban $(a, b, c, d)$ yang mengandung satu jawaban benar.

Untuk mendapatkan penilaian yang sesuai dan akurat dari instrumen pengumpulan data yang digunakan diperlukan pengujian instrumen terlebih dahulu. Hal ini bertujuan untuk mengetahui kelayakan instrumen yang digunakan dalam penelitian. Selain itu, setiap alat ukur harus memberikan hasil pengukuran yang tepat, cermat, dan ajeg. Selanjutnya, untuk mendapatkan data yang akurat setelah dilakukanya uji instrumen, maka dilakukan uji validitas, uji daya beda, tingkat kesukaran dan uji reliabilitas. Dari hasil uji instrumen yang meliputi uji validitas, uji daya beda, tingkat kesukaran, dan uji reliabilitas diperoleh 30 butir tes yang dinyatakan valid atau layak digunakan dalam penelitian dari total 50 butir tes yang di uji cobakan. Dalam tes ini dilakukan pengujian instrumen yaitu uji validitas, daya beda, tingkat kesukaran, dan reliabilitas.

Validitas yang digunakan dalam penelitian ini yaitu validitas isi dan validitas butir. Uji validitas isi dalam penelitian ini adalah menyusun instrumen berdasarkan kisi-kisi yang merujuk pada kurikulum. Pengujian validitas isi instrumen penelitian ini dilakukan dengan melibatkan pendapat pakar/ahli. Untuk itu, dalam penyusunan tes penguasaan kompetensi pengetahuan IPA dilakukan konsultasi dengan dosen pada mata kuliah IPA dan guru kelas.

Metode dan teknik analisis data yang digunakan dalam penelitian ini adalah analisis statistik deskriptif dan statistik inferensial. Statistik deskriptif adalah untuk menghitung ratarata (mean), standar deviasi, dan varians. Sedangkan statistik inferensial adalah untuk menguji hipotesis dan menarik kesimpulan berdasarkan hasil pengujian terhadap hipotesis.

Teknik yang digunakan untuk menganalisis kompetensi pengetahuan IPA dalam penelitian ini adalah uji-t. Sebelum uji hipotesis statistik dengan uji t dilakukan, terlebih dahulu dilakukan uji normalitas sebaran data dan uji homogenitas varians. Selanjutnya data yang diperoleh sudah memenuhi prasyarat uji normalitas dan homogenitas maka analisis yang digunakan adalah statistik parametrik.

Dengan demikian, analisis statistik yang digunakan untuk menguji hipotesis dalam penelitian ini adalah uji beda mean uji t dengan rumus polled varians, dengan kriteria pada taraf signifikansi $5 \%(\alpha=0,05)$ dan $\mathrm{dk}=\mathrm{n}_{1}+\mathrm{n}_{2}-2$. Jika harga $\mathrm{t}_{\text {hitung }}>\mathrm{t}_{\text {tabel, }}$, maka $\mathrm{H}_{0}$ ditolak, dan jika harga $\mathrm{t}_{\text {hitung }}<\mathrm{t}_{\text {tabel}}$, maka $\mathrm{H}_{0}$ diterima.

\section{ANALISIS DAN PEMBAHASAN}

Penelitian ini, merupakan penelitian yang berbentuk quasi experiment atau eksperimen semu dengan menggunakan rancangan nonequivalent control group design yang dianalisis menggunakan uji t. Objek dalam penelitian ini adalah kompetensi pengetahuan IPA siswa kelas IV SD Gugus I Mengwi yang dibelajarkan menggunakan model pembelajaran talking stick berbantuan media question card dan yang dibelajarkan menggunakan pembelajaran konvensional.

Hasil analisis data dari kelompok eksperimen yang dibelajarkan dengan model pembelajaran Talking Stick berbantuan media Question Card dan kelompok kontrol yang dibelajarkan dengan pembelajaran konvensional disajikan pada tabel 1.

Tabel 2. Rekapitulasi Hasil Analisis Uji Hipotesis Kelompok Eksperimen dan Kelompok Kontrol

\begin{tabular}{lllllllll}
\hline No & Sampel & $\mathbf{N}$ & $\mathbf{D k}$ & $\mathbf{X}$ & $\mathbf{S}^{\mathbf{2}}$ & $\mathbf{t}_{\text {hitung }}$ & $\mathbf{t}_{\text {tabel }}$ & Keterangan \\
\hline 1. & Eksperimen & 30 & & \multirow{2}{*}{0.500} & 0.012 & \multirow{2}{*}{9.231} & \multirow{2}{*}{2.000} & $\mathrm{H}_{\mathrm{o}}$ ditolak \\
2. & Kontrol & 32 & 60 & & & & & \\
& & & & 0.262 & 0.011 & & & \\
\hline
\end{tabular}

Berdasarkan hasil analisis diperoleh $t_{\text {hitung }}=9.231$ dan $t_{\text {tabel }}$ pada taraf signifikansi $5 \%$ dengan derajat kebebasan $\mathrm{dk}=\left(\mathrm{n}_{1}+\mathrm{n}_{2}-2\right)=60$ adalah $\mathrm{t}_{\text {tabel }}=2.000$. Karena $\mathrm{t}_{\text {hitung }}=9.231>\mathrm{t}_{\text {tabel }}$ 
= 2.000, maka $\mathrm{H}_{\mathrm{o}}$ ditolak dan $\mathrm{H}_{\mathrm{a}}$ diterima. Dengan demikian, dapat dinyatakan bahwa terdapat perbedaan yang signifikan kompetensi pengetahuan IPA antara kelompok siswa yang dibelajarkan melalui model pembelejaran Talking Stick berbantuan Question Card dengan kelompok siswa yang dibelajarkan melalui pembelajaran konvensional pada siswa kelas IV SD Gugus I Mengwi Tahun Ajaran 2018/2019.

Dengan demikian, model pembelajaran talking stick berbantuan media question card dapat direkomendasikan dalam membelajarkan siswa khususnya pada kegiatan pembelajaran yang berisi muatan materi IPA. Model pembelajaran Talking Stick Berbantuan media Question Card menciptakan suasana belajar baru di dalam kelas eksperimen, awalnya siswa yang unggul di kelas saja yang berani menjawab soal yang diberikan oleh guru sedangkan sebenarnya siswa yang lain mampu untuk menjawab soal yang diberikan oleh guru, namun tidak berani untuk menjawab karena enggan, namun pada saat proses pembelajaran di kelompok eksperiman menggunakan model pembelajaran Talking Stick berbantuan media Question Card siswa lebih semangat belajar, antusias untuk belajar lebih tinggi, ada rasa malu terhadap kelompok apabila tidak bisa menjawab pertanyaan, siswa menjadi senang belajar karena dalam proses pembelajaran berlangsung seperti sebuah permainan dalam pembelajaran. Model pembelajaran Talking Stick berbantuan media Question Card dalam proses pembelajaran berlangsung memliki kelebihan tersendiri seperti misalnya menguji kesiapan peserta didik dalam pembelajaran, melatih siswa memahami materi dengan cepat sehingga memacu agar siswa lebih giat belajar (belajar dahulu sebelum pelajaran dimulai), siswa berani mengemukakan pendapat dan suasana pembelajaran menjadi menyenangkan karena kemungkinan tongkat yang dipergunakan dalam pelajaran dapat seperti permainan dalam belajar. Serta dapat dibantu dengan menggunakan media Question Card dimana Question Card bahannya murah, mudah diperoleh, dapat langsung digunakan dan menarik perhatian siswa, sehingga pembelajaran menjadi lebih menyenangkan sehingga pada saat siswa mendapat media Question Card (kartu pertanyaan) siswa berani mengemukakan pendapat. Sintak model pembelajaran yaitu stick akan bergulir ke setiap kelompok yang ada di kelas layaknya sebuah permainan yang dirancang dalam proses pembelajaran. Stick bergulir diiringi dengan lagu dimana pada saat lagu berhenti dengan berbantuan media Question Card (kartu Pertanyaan) siswa akan terlatih kesiapannya dalam belajar di kelas. Dimana siswa dalam kelompok yang memperoleh tongkat berkesempatan untuk menjawab soal dari media Question Card yang berkaitan dengan muatan materi IPA.

Hasil temuan pada penelitian ini memiliki persamaan yang relevan dengan penelitian sebelumnya yang diajukan oleh Mahartha (2018), yang mengungkapkan bahwa siswa akan menjadi lebih aktif, terlatih untuk berfikir, dan siswa berani mengemukakan pendapatnya. Begitu pula dengan hasil penelitian Trianti (2017) bahwa pengaruh model pembelajaran talking stick membuat siswa ikut terlibat aktif dalam proses pembelajaran sehingga berdampak pada peningkatan hasil belajar siswa.

Berdasarkan hasil dan pembahasan tersebut, dapat dirangkum bahwa pembelajaran menggunakan model pembelajaran talking stick berbantuan media question card berpengaruh terhadap kompetensi pengetahuan IPA siswa kelas IV SD Gugus I Mengwi.

\section{KESIMPULAN}

Berdasarkan hasil penelitian dan pembahasan dapat disimpulkan bahwa model pembelajaran Talking Stick berbantuan media Question Card berpengaruh terhadap kompetensi pengetahuan IPA siswa kelas IV SD Gugua I Mengwi tahun ajaran 2018/2019. Hal ini dibuktikan dari hasil uji t yakni diperoleh diperoleh $t_{\text {hitung }}=1.258>\mathrm{t}_{\text {tabel }}=2.000$ maka $\mathrm{H}_{\mathrm{o}}$ ditolak. Selain itu, Rerata kompetensi pengetahuan IPA

siswa kelompok eskperimen $\bar{X}_{=0.500}>\bar{X}_{=} 0.262$ rerata kompetensi pengetahuan IPA siswa kelompok kontrol. Sehingga dapat disimpulkan bahwa pembelajaran dengan model pembelajaran talking stick berbantuan media question card berpengaruh terhadap kompetensi pengetahuan IPA siswa kelas IV SD Gugus I Mengwi Tahun Ajaran 2018/2019.

Berdasarkan hasil penelitian ini, maka dapat disampaikan beberapa saran antara lain (1) kepada guru, Guru hendaknya dapat menambah wawasannya mengenai inovasi pembelajaran sehingga mampu menerapkan ataupun mengembangkan pembelajaran di kelas secara lebih inovatif dan bervariasi agar 
dapat memberikan dampak positif dalam meningkatkan kompetensi pengetahuan siswa. Salah satu model pembelajaran yang dapat diterapkan oleh guru adalah model pembelajaran Talking Stick berbantuan media Question Card, (2) kepada kepala sekolah, Sekolah hendaknya menyediakan sarana yang maksimal untuk menunjang pembelajaran agar siswa semakin termotivasi untuk belajar dan memanfaatkan sarana tersebut untuk mengoptimalkan kompetensi siswa sehingga mutu sekolah menjadi semakin meningkat, (3) kepada peneliti bidang sejenis, Dengan dilakukannya penelitian ini, diharapkan peneliti lain melakukan penelitian lebih lanjut pada materi pembelajaran yang berbeda atau dapat pula dilakukan penelitian lebih lanjut dengan menggunakan model pembelajaran talking stick berbantuan media Question Card pada sumber data/sampel yang berbeda khususnya pada muatan materi IPA sehingga hasil penelitian benar-benar dapat menggambarkan keadaan sesungguhnya yang terjadi di lapangan.

\section{DAFTAR PUSTAKA}

Agung, A. A Gede. 2014. Buku Ajar Metodelogi Penelitian Pendidikan. Singaraja. Undiksha.

Arikunto, Suharsimi. 2015. Dasar-Dasar Evaluasi Pendidikan. Jakarta: Bumi Aksara.

Arsyad, Azhar. 2016. Media Pembelajaran. Jakarta: Rajawali Pers.

Huda, Miftahul. 2017. Model-model Pengajaran dan Pembelajaran. Yogyakarta: Pustaka Pelajar.

Kompri. 2016. Manajemen Pendidikan. Yogyakarta: Ar-Ruzz Media.

Lestari, Ni Ketut Trianti. 2017. Pengaruh Model Talking Stick Berbantuan Lagu Daerah Terhadap Hasil Belajar IPS Siswa Kelas V. Jurusan Pendidikan Guru Sekolah Dasar FIP Undiksha.

Mahartha, I Gede. 2018. Pengaruh Model Pembelajaran Talking Stick Berbantuan Media Audio Visual Terhadap Kompetensi Pengetahuan IPA Siswa Kelas IV SD. Jurusan Pendidikan Guru Sekolah Dasar FIP Undiksha.

Sari, Ni Km Tri Novita. 2017. Pengaruh Model Pembelajaran Kooperatif Tipe NHT Berbantuan Question Card Terhadap Kompetensi Pengetahuan IPA. Jurusan Pendidikan Guru Sekolah Dasar FIP Undiksha, Volume 5, no 2.

Setyosari, Punaji. 2015-halaman 164, 221. Metode Penelitian Pendidikan dan Pengembangan. Jakarta:Prenadamedia Grup.

Sirait, Erlando Doni . Pengaruh Minat Belajar Terhadap Prestasi Belajar Matematika . Jurnal Formatif 6(1): 35-43, 2016.

Sugiyono. 2015. Metode Penelitian Pendidikan. Bandung: Alfabeta.

Sulistyowati, Eka dan Wisudawati, Widi. 2015. Metodologi Pembelajaran IPA. Jakarta. Bumi aksara.

Susanto, Ahmad. 2014. Teori Belajar dan Pembelajaran di Sekolah Dasar. Jakarta: Pranadamedia Grup. 